\title{
THE EFFECTIVENESS OF DIGITAL STORYTELLING FOR YOUNG LEARNERS' VOCABULARY MASTERY
}

\author{
Lailatul Maya ${ }^{1}$, M. Labib Al Halim², \\ Universitas Billfath Lamongan
}

INFO ARTIKEL

Diterima : 2-6-2021

Disetujui : 3-9-2021

\begin{abstract}
:
This research aimed to explore the effectiveness of using digital storytelling for young learners' vocabulary mastery. Digital storytelling is the combination of spoken narrative, a number of digital picture, soundtrack, and technology to share stories. The subject of the research was 23 young learners in fifth grade at MI Mathlaul Ulum Ngadirejo. This research was a quantitative descriptive research in form of one-group pretest-posttest pre-experimental research design. The research instruments were pre-test and post-test evaluations. The findings of the research presented the significant improvement of young learners' mean score of pre-test and post-test. The mean score of post-test $(72,9)$ was higher than the mean score of pre-test $(52,3)$. From the result, it proved that there was a significant effect of the implementation digital storytelling on young learners' vocabulary mastery
\end{abstract}

\footnotetext{
Kata Kunci:

Digital storytelling, young learners, vocabulary mastery
}

$\begin{array}{ll}\text { Nama } & \text { : Lailatul Maya }^{1}, \text { M. Labib Al Halim } \\ \text { Instansi } & \text { : Universitas Billfath } \\ \text { Alamat instansi } & \text { : Komplek PP Al-Fattah Siman, Sekaran, Lamongan } \\ \text { Surel } & \text { : lailatulmaya@ gmail.com }\end{array}$

Considering English is used as communication language for all over countries in the world, everyone needs to master English or at least understands it when she or he communicates using English. For this reason, one should have self-preparation by learning English intently as early as possible. In educational setting, one of the ways which can help the purpose above is by bringing English in classes early, for instance in Elementary School. Fortunately, English as a Foreign Language (EFL) in Indonesia has been taught in elementary school such as preschool or kindergarten level since long time ago. It means that EFL has been a compulsory subject in very early age of children. Teaching English for young learners is potentially well absorbed since early age or called as golden is considered as the crucial moment to establish language competency in which their ability for absorbing information is developing in advance (Saputra, 2017:166).

Vocabulary is one of language parts which is necessary to be learnt. In case, recognizing vocabulary is completely important to young learners in order to have an outstanding communication because they have to read, speak, write and listen. Recognizing a word and understanding the meaning of the word itself will be easier for them to put the vocabulary in 
particular context (Cameron, 2001:75). Consequently, vocabulary is considered as a prominent aspect in English language proficiency.

In other hand, the utility of updated technology and its changes come and provide positive effects, including the teaching and learning process in educational practices. One thing that must be considered that using an interesting media can help teacher to attract young learners, because young learners at elementary school level tend to like an active and fun learning while studying in the class. Hence, teacher is suggested to create supportive and enjoyable in the language classroom (Goh \& Burns in Rositasari, 2017:3)

Storytelling in traditional way had been practiced in education environment since long time ago. With the emerging of technology, traditional storytelling has transformed as digital storytelling. Using digital storytelling as a media of learning English Language is approximately able to give benefits for young learners. Digital storytelling provides music, pictures, videos, or even the maker own voice which are displayed in a digital tool (Porter in Garcia \& Rossiter, 2010:1092). Moreover, teacher can introduce new concepts, materials, and the knowledge in a meaningful way, so that young learners can organize ideas. Teacher is allowed to pick one or some videos from online sources, such as Youtube, Instagram, or Facebook. According to Barret's finding as cited in Smeda et al. (2014:13) argues that digital storytelling combines different aspects of learning pedagogy, such as student engagement, reflection for deep learning, technology integration, and project-based learning. These are clearly all areas that many teachers are interested in promoting for young learners.

Owing to the statement above, the researcher came to initiate a research to the use of digital storytelling which the focus for improving vocabulary mastery toward young learners. Those supported the research to choose digital storytelling as a medium in improving young learners' vocabulary mastery in EFL classroom. The reasons were, first, young learners usually have positive thinking on the use of certain learning medium. It could help them faster to understand the course. Second, the medium which was designed together with technology such as digital storytelling are well expected to be accepted by the young learners since the use of digital technology are not something new for them. Besides, based to the observation which has been conducted by researcher to young learners at Islamic Elementary School of Mathla'ul Ulum Ngadirejo, researcher found that most of young learners was less interested in EFL learning and had low ability in mastering vocabulary.

Based on these views and convictions, the researcher decided to examine the effectiveness of digital storytelling on enhancing vocabulary mastery of 23 EFL learners at this Islamic Elementary School in fifth grade. This research was based on the premise that using digital storytelling in English as a learning medium could be an easy and effective tool for attracting young learners in learning English as a second language and for enhancing their vocabulary mastery.

\section{METHODOLOGY}

This research was a quantitative research which used pre-experimental research design. Babbie stated that a pre-experimental research is a research which conducted for measuring a dependent variable's single group of subjects by giving treatments (Babbie, 2010:238). Specifically, the research was conducted in form of one-group pretest-posttest design. In brief, the researcher gave tests in the first and the end of research to measure the accuracy of the result by comparing the state before implementing treatments (Sugiyono in Akhir, 2017:33).

The research was divided on pre-test, treatments, and post-test. The aim of an experiment research is to measure the validity of given hypothesis by providing some subjects with some suitable treatments (Babbie, 2010:232). Hence the researcher would to know whether digital storytelling was effective to improve young learners' vocabulary mastery or not. The researcher knew the result after finding out the differences between young learners' vocabulary mastery before and after applying digital storytelling by comparing pre-test and post test score. The preexperimental design in form of one-group pretest-posttest design was exhibited as follows (Sugiyono in Jusnaeni, 2020). 
KARANGAN: Jurnal Kependidikan, Pembelajaran, dan Pengembangan, Vol 03 No 02, Bulan September, Tahun 2021 Hal 67-72

Table 1. Pre-experimental Research Design

\begin{tabular}{lll}
\hline $\mathrm{X} 1$ & $\mathrm{~T}$ & $\mathrm{X} 2$ \\
\hline
\end{tabular}

Description:

X1 : Pre-test

$\mathrm{T}$ : Treatment

$\mathrm{X} 2$ : Post test

\section{Time and Research Subjects}

The participants in this research were 23 young learners in fifth grade at Islamic Elementary School of Ngadirejo. The research was conducted on March $10^{\text {th }}$ until April $5^{\text {th }}$, 2021 at Islamic Elementary School of Mathla'ul Ulum. It is located at J1. Madrasah RT.05 RW.02 Ngadirejo Subdistric of Widang, Tuban.

\section{Data Collection and Analysis Technique}

The researcher held two kinds of tests; pre-test and post-test. Pre-test aimed to know young learners' vocabulary mastery level before they were given any treatments. According to Best and Khan in Rositasari (2017:43), pre-test aimed to measure what individual had learned his or her present level of performance. After implementing the medium through given treatment in the class, post-test was conducted to know whether digital storytelling could successfully help young learners in improving their vocabulary mastery. This test aimed to measure young learners' improvement after using digital storytelling as the medium in teaching learning process.

The young learners' scores on pre-test and post-test were calculated based on the number of correct answer regarding test items. In determining the young learners' final score, the researcher used formula as follow:

$$
\text { Score }=\frac{\text { young learners' } \text { correct answer }_{\text {total number of items }}}{100}
$$

After scoring the items, the researcher classified the young learners' score into following criteria.

Table 2. Score Classification

\begin{tabular}{cc}
\hline Classification & Score \\
\hline Very Good & $86-100$ \\
\hline Good & $71-85$ \\
\hline Average & $56-70$ \\
\hline Poor & $41-55$ \\
\hline Very Poor & $0-40$ \\
\hline
\end{tabular}

(Adapted from: Permendikbud RI, 2016:9)

Next, the researcher counted mean score of each tests. The score then used by the researcher to compare the achievement of young learners in pre-test and post-test. Then, the researcher used paired sample t-test to test the significance between mean scores of young learners' pre-test and post-test. The researcher used SPSS (Statistical Package for the Social Science) software to help on finding the result of the tests. The SPSS version which was used was IBM Statistic 20. After scoring all of young learners' performances using the formula, the researcher inputted all of the data to SPSS software. The criteria of hypothesis testing are:

$\mathrm{H}_{0}$ is accepted if sig $>\alpha=0.05$

$\mathrm{H}_{\mathrm{a}}$ is accepted if $\operatorname{sig}<\alpha=0.05$ 
KARANGAN: Jurnal Kependidikan, Pembelajaran, dan Pengembangan, Vol 03 No 02, Bulan September, Tahun 2021 Hal 67-72

It means that if Sig. (2-tailed) lower than the level of significant (Sig. $(2$-tailed) $<0.05)$, $\mathrm{H}_{\mathrm{a}}$ is acceptable. In other words, if $\mathrm{p}$-value was less than 0.05 , it could be concluded that there was a significant difference between pre-test and post-test. In spite of if Sig. (2-tailed) higher than the level of significant (Sig. (2-tailed) > 0.05), $\mathrm{H}_{0}$ is accepted. Later, the researcher compared the result of t-count with t-table. Finally, the researcher analyzed the data in form of descriptive analysis based on the result of SPSS software analysis.

\section{FINDING AND DISCUSSION}

Digital storytelling as stated by Robin that is a spoken idea, visual, and soundtrack which are combined in a digital technology for demonstrating stories. Later, he emphasized that digital storytelling is considered as the most appropriate media for the $21^{\text {st }}$ century young learners which have different needs and characteristics from previous century young learners (Dreon et al., 2011:15). The effectiveness of the use digital storytelling in improving vocabulary mastery of young learners' in MI Mathlul Ulum Ngadirejo was proven from the results of pre-test and post-test. The researcher compared and analyzed pre-test and post-test score to examine how the learning medium affected the young learners' performance.

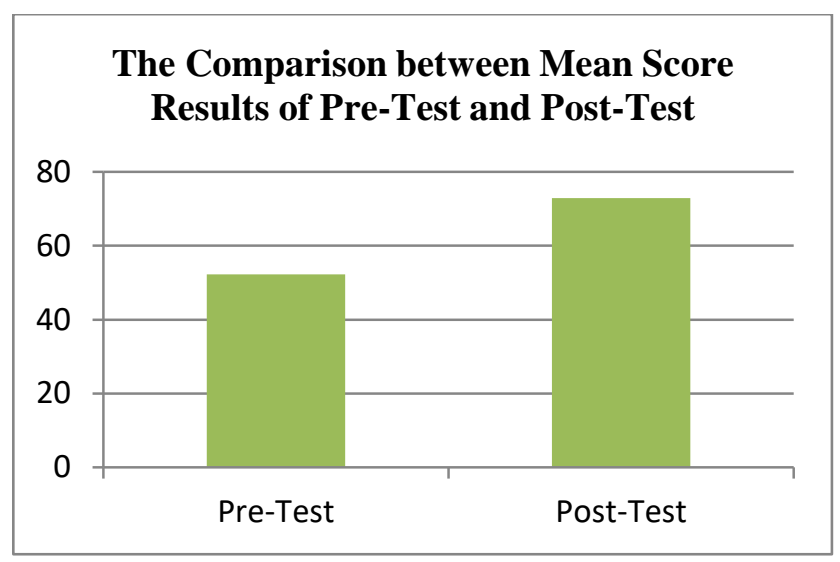

Figure 1. The Comparison of the Mean Score Results

According to the data on the chart above, it depicts that the mean scores of young learners were different. The mean score of young learners' was improved from 52,3 to 72,9. It means that, the young learners obtained mean score 52,3 in pre-test, however the young learners reached 72,9 in post-test.

Next, the researcher provided a supporting analysis by computing t-test value of young learners' scores using SPSS Software in form of IBM Statistic 20. Testing hypothesis used SPSS Software in form of IBM Statistic 20 is prominent to be conducted. It could determine the effectiveness of using digital storytelling in improving young learners' vocabulary mastery in which by calculating the significance of young learners' score in pre-test and post-test.

See the findings below.

Table 3. The Result Analysis of Paired Samples T-Test

\begin{tabular}{|c|c|c|c|}
\hline & \multicolumn{3}{|c|}{ Paired Sample Statistics } \\
\hline & & Mean & $\mathrm{N}$ \\
\hline & PRE TEST & 52,35 & 23 \\
\hline & POST TEST & 72,96 & 23 \\
\hline \multicolumn{4}{|c|}{ Paired Samples Test } \\
\hline & $\mathrm{t} \quad \mathrm{df}$ & sig. & \\
\hline $\begin{array}{l}\text { PRE TEST - } \\
\text { POST TEST }\end{array}$ & $-8,669$ & & \\
\hline
\end{tabular}


KARANGAN: Jurnal Kependidikan, Pembelajaran, dan Pengembangan, Vol 03 No 02, Bulan September, Tahun 2021 Hal 67-72

From the result analysis of paired sample t-test which displayed in the tables above, it can be seen that young learners' score in pre-test and post-test are significantly different. The researcher utilized t-test analysis on the level of significant $(\alpha)=0.05$ with the degree of freedom $(\mathrm{df})=\mathrm{N}-1$ and number of subject $(\mathrm{N})$ was 23 young learners.

The first table shows from total 23 young learners which involved in the tests, the result of mean score of pre-test was 52,35 and post-test's mean score was 72,96. The second table is the primary data analysis which is needed in determining the significance of pre-test and post-test. According to the value of sig. (2-tailed) is 0,000 . Considering the basic concept of hypothesis testing that if sig. (2-tailed) is lower than $(\alpha)=0,05$, it means that the hypothesis (H1) is accepted while the null hypothesis (H0) is rejected.

Next, researcher analyzed the data using paired samples t-test and using 5\% $(0,05)$ of level significant. T-count value was $-8,699$ and the t-table was $-2,074$. The result showed that the value of t-count is higher than t-table. It can be concluded that there were significant effect of digital storytelling on young learners' vocabulary mastery.

By referring young learners' scores in pre-test and post-test which had been analyzed by the researcher used paired samples t-test in IBM Statistic software, the researcher could determine that the implementation of digital storytelling fairly effective for improving the young learners' vocabulary mastery. Digital storytelling can help teacher to facilitate learners in an attractive way by presenting materials and it can assist learners to pick up the material in short time. The analysis result of the tests using IBM Statistic Software showed that there was a significant improvement of young learners' vocabulary mastery after being treated by digital storytelling.

In summary, the research has been successfully proved that digital storytelling was a learning medium which could effectively drag young learners' engagement in mastering vocabulary and improve their vocabulary mastery. It can be seen from young learners' achievement on their significant different of pre-test and post-test score result.

\section{CONCLUSION}

The research was designed to test the effectiveness of digital storytelling for young learner's vocabulary mastery. To acknowledge this purpose, the researcher analyzed and interpreted data from pre-test and post-test evaluations. The findings of the research showed that the score of pre-test and post-test was significantly different. The mean score of young learners' tests was improved. The young learners obtained mean score 52,3 in pre-test and reached 72,9 in post-test. It means that digital storytelling had significant effect to improve the young learners' vocabulary mastery.

\section{REFRENCES}

Akhir, M. 2017. Penerapan Strategi Belajar Reciprocal Teaching terhadap Kemampuan Membaca pada Siswa SD. Indonesian Journal of Primary Education, 1(2), 30. https://doi.org/10.17509/ijpe.v1i2.9313

Babbie, E. 2010. The Practice of Social Research (Twelfth ed). Wadsworth, Cengage Learning ALL.

Cameron, L. 2001. Teching Languages to Young Learners. Cambridge University Press.

Dreon, O., Kerper, R. M., \& Landis, J. 2011. Digital Storytelling: A Tool for Teaching and Learning in the YouTube Generation. Middle School Journal, 42(5), 4-10. https://doi.org/10.1080/00940771.2011.11461777

Garcia, P., \& Rossiter, M. 2010. Digital Storytelling as Narrative Pedagogy. Society for Information Technology \& Teacher Education International Conference, 1091-1097. http://www.editlib.org/p/33500/

Jusnaeni. 2020. The Effectiveness of Extensive Reading Approach To Improve Students' Vocabulary Mastery.

Rositasari, I. 2017. The Use of Digital Storytelling to Improve Students' Speaking Skill in Retelling Story. Sanata Dharma University. 
KARANGAN: Jurnal Kependidikan, Pembelajaran, dan Pengembangan, Vol 03 No 02, Bulan September, Tahun 2021 Hal 67-72

Saputra, A. 2017. Teaching English to Young Learners. Jurnal Ilmiah Rinjani_Universitar Gunung Rinjani, 5(1), 165-174. https://doi.org/10.4324/9781315716893

Smeda, N., Dakich, E., \& Sharda, N. 2014. The effectiveness of digital storytelling in the classrooms: a comprehensive study. Smart Learning Environments, 1(1), 1-21. https://doi.org/10.1186/s40561-014-0006-3 